\title{
4 Changes in the Poetics of Song during the Finnish Reformation
}

\author{
Kati Kallio
}

In sixteenth-century Finland, the Reformation marked not only the beginning of the Finnish written language, but also a slow, fundamental, and long-lasting change in poetics and music. Stanzaic and rhymed poetics first appeared in new Lutheran hymns and went on to take over the whole sphere of folk singing in Western Finland over a couple of centuries. The poetic features of vernacular Lutheran hymns varied by time, poet, and genre of singing, and these changes may be connected with the changes in historical and ideological contexts. The focus of this chapter is on the first three important translators and creators of Finnish liturgical songs, Michael Agricola (c. 1510-1554), Jacobus Finno (c. 1540-1588), and Hemmingius of Masku (c.1550-1619). They were all clergymen in the diocese of Turku (Swe. Åbo), consisting of the western and southern parts of modern Finland. At the time, the area was the most eastern diocese of the Kingdom of Sweden. The language of Church was Latin, while the languages of trade and secular administration were mostly German and Swedish. From the period prior to the Reformation there are no sources of literate Finnish language or rhymed poetics. The old oral idiom, the Kalevala metre, was built on alliterative trochaic verses with no rhymes or stanzas, and sung with narrow melodies of one or two lines.

The sources and contents of the early Finnish hymn melodies and texts, the role of the translators, and the relationships of the first hymnals to ecclesiastical history have been analysed, but the poetics have not been given much attention. From the nineteenth century on, these early hymns have been regarded as too formless to warrant more detailed poetic scrutiny. It has been asked, why did the early reformers even choose to use these new rhymed poetics, which were laborious to apply to Finnish, when they could

1 See eg. Heininen, Mikael Agricola; Häkkinen, 'Maskun Hemmingin'; Häkkinen and Vaittinen, Agricolan aika; Knuutila, 'Virsikirjat'; Kurvinen, Suomen virsirunouden; Kurvinen, Vanha virsikirja; Laine, Luther, reformaatio; Laitinen, 'Barokki tunteen'; Lavery, 'The Reformation'; Leino, Language and Metre; Lempiäinen and Haapalainen, Virsiavain; Pajamo and Tuppurainen, Suomen musiikin; Pirinen, Suomen kirkon; Väinölä, Vanha virsikirja; Voipio, Virsiemme synty. 
have used the old Finnic oral poetic idiom, the so-called Kalevala metre? ${ }^{2}$ The question partly derives from the poetic and national ideals of the early twentieth century, projecting modern ideas of identity, Lutheranism, and good poetry on the past. The ethnomusicologist Heikki Laitinen has opposed this view by noting that, supposedly, for their authors and original audiences, these poems were not clumsy texts but enjoyable songs. ${ }^{3}$ Here, it seems essential to try to understand what these translators and song makers were doing in relation to the poetic and musical cultures, meanings, and aesthetics they were familiar with.

In this chapter, I examine the changes in Finnish poetics at the time of the Reformation in an attempt to understand their temporal variation, relations to other oral and written poetics, and the complex relationships of poetics, music, and identities. This involves reading the early hymnals, musical manuscripts, and earlier research on relevant fields and a more detailed analysis of some representative examples. Finnish hymn poetics are contextualized within medieval liturgical genres, German and Scandinavian hymn traditions, and what we may deduce about the oral vernacular poetics of the time. The chapter thus draws together earlier research on the subject in various scholarly fields, re-reads and develops it, and, with some examples, investigates directions for future analyses.

Three theoretical strands inform my approach. In ethnopoetics, the aim has been to recognize poetic forms and aesthetics, which do not follow

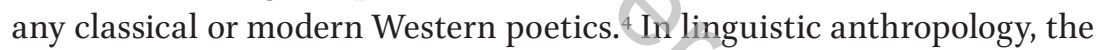
linguistic repertoires (here applied to poetics) are seen as local, temporal, and context-bound registers, tied to particular speech communities. Linguistic forms, genres, and styles are, by the members of a speech community, associated with typical contents, users, and contexts of use. The forms gain their meanings through these shared associations. ${ }^{5}$ In ethnomusicology and folkloristics, it has been noted that when studying poetics and meanings of songs, the relationships between the musical and textual forms need to be taken into account. ${ }^{6}$ Thus, the focus of this chapter is on the aesthetics of

2 Krohn, Suomalaisen kirjallisuuden; Rapola, 'Vanhan runon'; Sarajas, Suomen kansanrunouden, pp. 16-17; Tarkiainen, Piirteitä suomalaisesta.

3 Laitinen, 'Barokki tunteen', p. 153-156; Laitinen, Matkoja musiikkiin, pp. 183, 211.

4 Hymes, 'In vain I tried'; Tedlock, The Spoken Word.

5 Agha, Language and Social; Duranti, Linguistic Anthropology.

6 Harvilahti, The Holy Mountain, pp. 78-81; Kallio, Laulamisen tapoja, pp. 128-30; Laitinen, Matkoja musiikkiin, pp. 205-300; Lippus, Linear Musical Thinking, pp. 39-42; Niemi, The Nenets Songs, pp. 24-45. 
particular historical speech communities, the development of song genres, and the relationships between poetic styles and musical structures.

\section{The Reformation and Lutheran Hymns in Sweden}

Scholars have noted that the process of the Swedish Reformation was a slow one, and that there was a constant alternation between more Lutheran and more Catholic views. ${ }^{7}$ In addition, Finland has been characterized as a conservative district: not all the Reformation changes adopted in Germany or even in the Swedish-speaking areas of the same country were immediately put into practice. $^{8}$

The leading reformer in Stockholm, Olaus Petri (1493-1552), published his first translations of Lutheran hymns in Swedish in 1526. The Swedish New Testament was published in $15^{26}$, the first preserved larger hymnal of 45 songs in 1536, and the whole Bible in 1541. The Diet of Västerås in 1527 announced that the Word of God should be preached 'purely', the king had the right to take over the possessions of the Church, vernacular could be used in the Mass, and priests were allowed to marry. The Swedish Church Order in 1571 suggested the Mass should be held in vernacular languages, that is to say in Swedish or Finnish, but it was only slowly that these became the main languages of the Mass. ${ }^{9}$

In Finland, the first Lutheran bishop of Turku was Martin Skytte (c. 14801550), a former Dominican theologian and prior, who sent several students to Wittenberg. One of these, Michael Agricola, published in Finnish the most central liturgical texts such as the New Testament, Handbook, Prayer Book and Order of the Mass in 1543-1552. He created the Finnish literary language, although it is evident he had some collaborators and predecessors (see the chapter by Tuomas M.S. Lehtonen). Nevertheless, the first Finnish hymnal was not published until 1583 , and the first choral book with musical notation until 1702. Hitherto, the hymn texts and melodies circulated orally and via manuscripts. ${ }^{10}$ The hymns were not the first priority, as the Reformers did

7 See Andrén, Sveriges kyrkohistoria; Pahlmblad, Mässa på svenska; Pirinen, Suomen kirkon; see also the chapter by Berntson in this volume.

8 Laine, Vanhimman suomalaisen; Lavery, 'The Reformation'; Pirinen, Suomen kirkon; Schalin 1946-1947.

9 Andrén, Sveriges kyrkohistoria; Liedgren, Den svenska psalmboken; Pahlmblad, Mässa på svenska; Schalin, Kulthistoriska studier; see also the chapter by Berntson in this volume.

1o Heininen, Mikael Agricola; Knuutila, 'Virsikirjat'; Pajamo and Tuppurainen, Suomen musiikin. 
not have that many resources for translations and printing. In addition, it seems there were no models for stanzaic, rhymed, and iambic songs in the Finnish language. ${ }^{11}$

We know some vernacular hymns from the medieval period in Swedish, and Germany is known for medieval vernacular Christian song traditions, but these did not constitute any significant part of the liturgy. Thus, the Lutheran vernacular congregational singing at Mass was something new, and not shared by all the Reformed movements. Jean Calvin (1509-1564), for example, regarded only the biblical Psalms as apt for liturgical use.

For Luther, the hymn became a practical way to convey the biblical contents in understandable, appealing vernacular form. He called for poets in the early phase of the Reformation, and wrote 37 hymns himself. Luther and his friends composed the very first Lutheran hymns in 1523-1524, with several booklets of 8-32 hymns appearing in 1524 . The total sum of different German hymn editions during the sixteenth century was almost 2000. ${ }^{12}$ The first hymns were mainly catechetical, consisting of the basic themes of Christian faith. Luther used and moulded the traditional melodies of Catholic hymns and spiritual folk songs, and composed some melodies himself. He did not use the melodies of secular songs in congregational hymns, although this was sometimes done later on. The role of the hymns and congregational singing in the German Reformation has been disputed. Nevertheless, it is evident that the hymns became very popular. ${ }^{13}$ When, in his preface to the first Finnish hymnal, Jacobus Finno describes how he saw people singing hymns everywhere in Germany, he might not have been exaggerating too much. ${ }^{14}$

While the hymns are often emphasized when deseribing Lutheran traditions, it is important to note that Luther in fact also retained many of the earlier singing traditions. He based his Latin and German Masses on unmeasured chant, and also kept late medieval polyphonic choral songs in use. Even though the use of the vernacular in the liturgy is often seen as one of the characteristics of the Reformation, Luther did not ban the use of Latin as such. It was fine to have the Masses in Latin, when the congregation knew the language. It was also appropriate to use several languages, and to make various adaptations according to local needs. In fact, most of the

11 Kurvinen, Vanha virsikirja, pp. 10-11; Kurvinen, Suomen virsirunouden, pp. 58-67.

12 Brown, 'Devotional Life', p. 233.

13 Anttila, Luther's Theology; Brown, Singing the Gospel; Leaver, Luther's Liturgical, particularly pp. 17-18.

14 Finno,Jaakko Finnon, p. 15; see the chapter by Lehtonen in this volume. 
liturgical songs in Luther's German Mass (1526) were unmeasured ones for the clergy and the choir, and it was only slowly that the metrical hymns for the congregation began to replace unmeasured ones. ${ }^{15}$

\section{Poetic Metres in Finnish}

The metrics of the first Finnish hymns are not easy to interpret. Yet the poeticfeatures of these songs - incomplete rhymes, shortened words, varying numbers of syllables in metrical positions, and varying ways to actualize the patterns of stress - were typical of vernacular poetics in northern Europe at the time, although some Finnish poets made use of these features to an exceptional degree. ${ }^{16}$ To understand these songs calls for a familiarity with the basics of both the traditional oral metre and the new rhymed poetics.

The dating of Finnish oral poetics is problematic. The very first sources of both the traditional Kalevala metre and rhymed metres date from the sixteenth century, but while the Kalevala metre is supposed to date back several thousand years, the rhymed metres are thought to have been adapted to the Finnish language only around the sixteenth century. The age of the Kalevala metre is deduced from its use within a wide range of Finnic languages (Finnish, Estonian, Karelian, Izhorian, Vote) and genres (epic, lyric, ritual and occasional poetry, proverbs, charms and lullabies), but also because the metre suits the archaic form sof Finnic words with ease. ${ }^{17}$ In the first scholarly descriptions of Finnish poetry from the seventeenth century on, the Kalevala metre is described as the old and original form of the Finnish language. ${ }^{18}$ Thus, it is reasonable to suppose that, in the context of early modern Finland, Kalevala metre was understood as the traditional oral metre of the Finnish language.

The age of Finnish rhymed poetry is even more ambiguous. The rhymed folk poetry did not interest the scholars of later centuries enough to be recorded or described to any significant degree, which means the evidence is fragmentary. The first few Finnish mocking songs in the court records of

15 Bonn, 'Plainsong'; Helmer, 'Catholic Luther', pp. 164-5; Herl, Worship Wars; Leaver, Luther's Liturgical, pp. 18, 144, 180-191.

16 See Gasparov, A History, pp. 194-7; Gillespie, German Baroque; Göransson, 'Musiken', p. 262; Laitinen Matkoja musiikkiin; Laitinen, 'Barokki tunteen', p. 156; Leino, Language and Metre; Kurvinen, Vanha virsikirja, pp. 22-4.

17 Korhonen, 'The Early History'; Kuusi, 'Questions'; Leino, 'The Kalevala Metre'; see Tarkka, Songs of the Border on the genres of poetry.

18 See Laitinen, 'Runolaulu'; Kallio, 'Kalevalamitta'. 
the seventeenth century represent both Kalevala metre and rhymed and hybrid forms. ${ }^{19}$ Some short rhymed Christian stanzas similar to German and Scandinavian vernacular traditions could have been used already in late-medieval Finland, although the evidence for this is indirect. ${ }^{20}$ The first ample source of rhymed songs in the Finnish language is the Lutheran hymnal $(1583,1605)$. On the basis of this kind of evidence, it has been concluded that the development of Finnish rhymed folk metrics could have begun around the time of the Reformation. ${ }^{21}$ Yet on the basis of coastal trade contacts as described by Ilkka Leskelä in Chapter 2, it seems possible that the first versions of rhymed, stanzaic, or word-stress-based songs could have been created at any time from the twelfth century onwards, when these forms became common in German and in Scandinavian languages and were probably heard in coastal areas, while the rhymed Latin songs were used in ecclesiastical contexts. ${ }^{22}$ Still, it seems probable that the Kalevala metre remained the dominant Finnish folk metre up to the eighteenth century even in coastal areas. ${ }^{23}$

Kalevala metre is a trochaic tetrametre with specific 'broken verses' consisting of more or less half of the verses. In a broken verse, a short stressed syllable is situated at the fall of a poetic foot, giving a characteristic syncopation to the metre. Thus the metre is based both on the stress of the syllables and on their length: a long stressed syllable should be at a rising, a short one at a falling position. A verse typically has from eight to ten syllables, two to four syllables in the first foot. The most recognizable feature of the verse is the ample alliteration. Rhyme is not used, and the poems have no stanzaic structure, but parallelism is frequent. ${ }^{24}$

The Finnish stanzaic, rhymed poems and songs are usually based on the stress of the words only. Typically, the rhymed songs are not based on alliteration or parallelism, although these may occur. Rhymed songs contain both iambic and trochaic metres with different verse length and stanza forms. Owing to the characteristics of the Finnish language - the main stress is always on the first syllable of a word and there are few one-syllable words - strictly iambic metres have posed some problems to poets. In iambic

19 See Asplund, 'Runolaulusta rekilauluun', pp. 109-12.

20 Gummerus, 'Onko katolisella'; Maliniemi, 'Kansankieli'; see also the chapter by Grudule in this volume.

21 Asplund, 'Runolaulusta rekilauluun'; Leino, 'The Kalevala Metre', pp. 56-7.

22 On the history of rhymed songs in other languages, see Gasparov, A History; Page, The Christian West.

23 Kallio, 'Kalevalamitta'.

24 Kuusi, 'Questions'; Leino, Language and Metre; Tarkka, Songs of the Border. 
metres, iambic inversion $(/ \backslash \backslash)$ is common. Typically, in early hymns and later folk songs alike, each metric position may be filled variably with one or two syllables, although there are also strictly syllabic metres. Similarly, the actualized patterns of stress vary. ${ }^{25}$

In metric contexts, the syllable boundaries between vowels may sometimes be interpreted in several ways ('koet-taa' or 'ko-et-taa'). In rhymed metres, some two-syllable words (terue, sine) may be counted as stressed or unstressed. ${ }^{26}$ Varying dialectical forms and the unstable character of literary language pose some problems in the metrical analysis of the early hymns. Shortened words were typical of the western dialects used in the early hymns, but Kaisa Häkkinen points out that it was possible for each reader to pronounce literate texts according to his or her own dialect. ${ }^{27}$ In the following examples, the syllables with main stress and those with both secondary and poetic stress are in bold, and ${ }^{\circ}$ marks an ambiguous verse.

\section{Michael Agricola: Translating Medieval Traditions}

The headmaster of the cathedral school of Turku, Michael Agricola, took on the task of translating and publishing the central texts of the Finnish Reformation: the Catechetical Primer, the Prayer Book, the New Testament, the Mass, the Handbook, the Passion, and the Psalter. His main achievement, the creation of the Finnish literary language, is regarded as a success. His biblical prose translations were used as a base for new versions up to the nineteenth century. ${ }^{28}$

The majority of Agricola's Finnish verses are found in prefaces to his translations. ${ }^{29}$ Apparently, he did not compose the prefaces to be sung. Apart from these poems, Agricola published 39 translations of medieval liturgical songs and hymns in his Prayer Book and Mass, mostly short and unmeasured ones. Only five of his hymns are strictly measured, and he

25 Asplund et al., Suomen musiikin; Laitinen, Matkoja musiikkiin; Laurila, Suomen rahvaan; Leino, Language and Metre.

26 Laitinen, Matkoja musiikkiin; Leino, Language and Metre, pp. 71-5.

27 Häkkinen, 'Maskun Hemmingin', p. 28.

28 Heininen, Mikael Agricola; Häkkinen and Vaittinen, Agricolan aika.

29 These are written in rhymed knittel (doggerel) verse with four accents and varying numbers of syllables in each metric position: see Mikael Agricolan runokirja. 
did not translate new Lutheran hymns. ${ }^{30}$ This has all been interpreted to indicate his limited interest in singing.

Nevertheless, it would be a mistake to equate songs with metrical texts. In Catholic tradition, the singing and chanting in Mass and in the Divine Office (Liturgy of Hours) was mostly unmeasured, and here, the most central texts were biblical. Thus, the Prayer Book, New Testament, Mass, and Psalter by Agricola could all be regarded as kinds of songbooks, although unmeasured ones. Indeed, the unmeasured Psalter was traditionally regarded as the most important songbook, comprising the central corpus for the Divine Office.$^{31}$ This changes the perspective on Agricola's attitude towards songs: he did in fact translate texts to be sung, although these were not measured songs for the laity.

Liturgical unmeasured chant was maintained during the first century of the Finnish Reformation, as can be seen in the chapter by Erkki Tuppurainen and Jorma Hannikainen in this volume. While preparing his German Mass, Luther emphasized the need to make appropriate musical adaptations when creating vernacular liturgical chant..$^{2}$ The texts of the Bible and other central liturgical texts had to be translated accurately, and music was the part to be adapted to the changes in linguistic structures. Typically, as Tuppurainen and Hannikainen note, the Finnish musical applications of unmeasured liturgical texts were not very elaborate, but they apparently served the needs of the vernacular service well enough. ${ }^{33}$ Agricola meant his translations of the biblical and liturgical prose texts to be used also as songs or recitations, but when translating these, he did not need to create poetic structures or to try to adapt the texts to musical patterns. Those using the unmeasured texts as recitations or songs could make the necessary musical adaptations.

Metrical hymns were not an invention of the Reformation, but deeply rooted in Catholic tradition at least from the third century on. Most of these were not used in Mass proper, but in the Divine Office and in non-liturgical contexts. In the publications by Agricola, Erkki Tuppurainen has recognized 39 song texts, of which - depending on the interpreter - five or eighteen are seen as more or less measured. At least three of the five most measured songs seem to derive from earlier translators, as they are also found in the

30 Häkkinen, 'The Rise', p. 15; Kurvinen, Vanha virsikirja, pp. 10-4; Tuppurainen, 'Westhin koodeksi'.

31 Boynton, 'Plainsong'; Boynton, 'Prayer'; Hornby, Medieval Liturgical; Voipio, Virsiemme synty, pp. 16-9.

32 See Leaver, Luther's Liturgical, pp. 63-4, 180-91.

33 See also Hannikainen 2006; Tuppurainen, 'Westhin koodeksi'. 
manuscript Codex Westh (dated 1545-1549) in slightly different forms. ${ }^{34}$ All of the songs published by Agricola relate to Latin medieval tradition: traditional hymns, antiphons, sequences, and introits. He did not publish new German hymns except for the Agnus Dei (O Lamm Gottes unschuldig) deriving from a medieval trope. Some metrical Latin songs he translated as plain prose. ${ }^{35}$ Although the prose texts by Agricola are appreciated, he is acknowledged as being a lousy poet, concentrating on accurate content, not on poetics. ${ }^{36}$

In the five most metrical songs Agricola published, the number of syllables and the stress pattern in a verse is quite regular. None of his songs follows a regular pattern of rhyme, although some occasional rhymes appear. His most regular poem is one of the most central Catholic sequences, 'the Golden Sequence', Veni sancte Spiritus, et emitte coelitus ('Come, Holy Spirit, and from heaven direct'), found in both Agricola's Prayer Book and in Codex Westh. It was popular in sixteenth-century Finland both in Latin and in Finnish. ${ }^{37}$

\begin{tabular}{ll}
\hline $\begin{array}{l}\text { TUle| Pyhe| hengi| ten } \\
\text { alas|laske| Taijua|hast } \\
\text { sinun| paijstes| walke|us }\end{array}$ & $\begin{array}{l}\text { Come, Holy Spirit, here, } \\
\text { send down from the heaven }\end{array}$ \\
Tule| kieuhet|ten I|se & the brightness of your light. \\
tule| lahian| andai|ja & Come, father of the poor, \\
tule| sijelun| kirca|us. & come, gift-giver \\
\hline
\end{tabular}

Here, the trochaic pattern $(/ \backslash / \backslash / \backslash /)$ is very clear. The poem is based on the stress of syllables and on regular verse length. The character of this regularity appears exceptional when compared to other measured poems in the Prayer Book.

34 P.I. Kurvinen (Suomen virsirunouden, pp. 221-39) analysed thirty songs in the publications by Agricola, twelve defined as pure prose. For him, a stanzaic form or rhythmic language seems to be enough to recognize the song as non-prose. Viljo Tarkiainen (Mikael Agricolan, p. 9) identified thirty songs, and claimed only five of these are measured. He had strict demands for the rhymes and the regularity of verses. Finally, Erkki Tuppurainen ('Westhin koodeksi', pp. 32-3) has identified 39 liturgical songs (mostly unmeasured, not including the 85 biblical psalms), and notes that most of these are prose and some were probably not meant to be used as songs.

35 Häkkinen, 'The Rise', p. 15; Kurvinen, Suomen virsirunouden, pp. 221-39; Tuppurainen, 'Westhin koodeksi', pp. 35-6.

36 Harjunpaa, 'A Historical Outline,' p. 157; Häkkinen, 'The Rise', p. 15; Kurvinen 1941, p. 12; Tarkiainen, Mikael Agricolan, pp. 12-3; Tuppurainen, 'Westhin koodeksi', p. 36.

37 Kurvinen, Suomen virsirunouden, pp. 230-1; Codex Westh, 2012, pp. 17, 36-8.

38 Agricola I, p. 409. 
The second example is the first stanza of another classic Catholic hymn Christe, qui lux es et dies ('O Christ who art the light and day'), found also in the Codex Westh: ${ }^{39}$

\begin{tabular}{ll}
\hline CHristus| se paijs|te ia peij|ue on & Christ is the light and the day \\
quin öön| pimey|dhet hai|jotat & you dissolve the darkness of the night \\
sine wal|keud|hen wal|keus & you, the light of light \\
sarna|tat py|hen paijs|teen. ${ }^{40}$ & you preach the sacred shining. \\
\hline
\end{tabular}

Here, the metre follows an iambic tetrameter $(\backslash / \backslash / \backslash / \backslash /)$, but the number of syllables in a metrical position varies, and in the first poetic foot in particular the stresses may vary. In the first stanza, alliteration appears in three verses out of four, although only in six of the next 24 verses. No rhyme is used.

In the third example, the metrical scheme is similar, but the realization ever broader. This example is the first stanza of an old Latin hymn of the Divine Office, O crux aue spes unica redemptorum que gloria ('Hail, O Cross, our only hope'). ${ }^{41}$

\begin{tabular}{ll}
\hline TErue Chris|te aij|noa toij|uo & ${ }^{\circ}$ \\
sine Lu|nastet|tudhen cun|nia & Hail Christ, the single hope, \\
lise Ju|malal|listen hurs|caut & the glory of the redeemed \\
ia an|na syn|neisten an|dexi ${ }^{\circ} .^{2}$ & increase the devoutness of the godly \\
\hline
\end{tabular}

Here, the poem follows an iambic tetrameter $(\backslash / \backslash / \backslash / \backslash)$, but yet more loosely than in the previous example, raising possibilities of various metric interpretations. There may be one or two syllables in a non-stressed position, but the ends of the lines are more regular. No rhyme appears, but alliteration is used in three verses of the eight in the short poem.

The three examples are built on different metrical principles. Evidently, rhyme was not an important feature in these translations: in the examples, only the third and sixth lines of the first example are rhymed. In the Latin hymn tradition, rhyme was used sometimes regularly and sometimes,

39 Kurvinen, Suomen virsirunouden, pp. 235-7; Codex Westh, pp. 92-4.

40 Agricola I, p. 681.

41 Kurvinen, Suomen virsirunouden, pp. 227-8.

42 Agricola I, p. 361. 
especially in the older hymns, only occasionally. ${ }^{43}$ Of all the songs published by Agricola, the two trochaic poems of the Prayer Book ('TUle Pyhe hengi ten'; 'TUle pyhe lodhuttaia') are most regular. ${ }^{44}$ In the most regular iambic poems, the numbers of syllables and the stress patterns vary more. This is in line with the common estimation that the iambic patterns were more difficult to apply to Finnish than the trochaic, owing to the prevailing oral trochaic tradition and the structure of the language. All of these poems are far from the oral Kalevala metric idiom, but in the iambic poems, alliteration is allowed.

The avoidance of Kalevala metre used to be interpreted as avoidance of either pagan or Catholic connotations of the metre, since it is evident that pre-Christian mythological poetry was in Kalevala metre and that this oral poetry had, by the time of the Reformation, adopted many Catholic themes. ${ }^{45}$ Yet, as suggested by the occasional uses of alliteration in iambic hymns, the degree of avoidance of features connected with Kalevala metre depended on the context. This is clearly illustrated in the case of the traditional proverbs. Agricola used one Kalevala-metric proverb in the preface of an unpublished manuscript and included one proverb and one rote in the calendar of the Prayer Book. Thus, it was clearly not about the total avoidance of the form itself, but about the suitability of particular forms to different genres and contexts. There was a long tradition in collecting and using Christian, classical, and vernacular proverbs: the genre was conceived as neutral. ${ }^{46}$ In contrast, the hymns evidently needed to be separated from the old oral folk idiom.

The scant number of measured hymns in the publications of Agricola may derive not only from difficulties in creating new iambic metres, the poor poetic talents of the translator, lack of resources, or the rush to translate the most important liturgical prose texts first. Another factor may be the inclination to follow locally esteemed traditions of the Church. In the preface of the Psalter Agricola describes the traditional practice of singing or reciting the Psalter in the Divine Office: 'so let the priests read their verses two by two in turn, as has been, and should be, the custom in choir'. ${ }^{47}$ In the preface of the Prayer Book he urged the priests to read prayers in Finnish to their people both before and after the sermon, but not to forget to practise Latin in order to be learned

43 About Latin hymns, see Voipio, Virsiemme synty, p. 26.

44 Kurvinen, Suomen virsirunouden, p. 73.

45 Tarkiainen, Mikael Agricolan, pp. 8-9; Viinamäki, Hemminki Maskulainen; Voipio, Virsiemme synty, p. 107; see also Lehtonen, 'Spoken, Written', p. 114; and the chapter by Järvinen in this volume. 46 Sarajas, Suomen kansanrunouden, pp. 5-9; see also Kallio, 'Kalevalamitta'.

47 'Nin caxi ia caxi Wersuns woroin / lukecan Papit / quin on Chorin // Tapa ollut / ia oleman pite //' (Agricola III, p. 211). 
enough to be able to teach the people well. ${ }^{48}$ Agricola notes in his Handbook and Mass that it was also possible to use Latin and Swedish hymns, and these hymns were often interchangeable with passages or psalms from the Bible. ${ }^{49}$

It seems Agricola wanted to maintain the traditional song genres of the medieval Church, partly translated into the vernacular, partly still in Latin. In addition, he may have been a realist. Introducing new Lutheran congregational singing on a large scale could have been laborious and caused resistance both among the clergy and the laity. In some other Swedish dioceses, there were local revolts connected with the changes in the cult; in the diocese of Turku there were none (see the chapter by Martin Berntson in this volume).$^{50} \mathrm{~A}$ certain caution and patience in introducing new practices could have been a deliberate choice, as noted by Jason Lavery. ${ }^{{ }^{1}}$

All in all, the texts published by Agricola were enough to hold the Lutheran vernacular services of the time with all the singing that was needed. The linguist Kaisa Häkkinen has noted that his publications 'included all the basic literature that a Finnish clergyman of the Early Reformation needed in his work..$^{2}$ He translated into the vernacular the most important liturgical prose texts and some medieval hymns. It was not yet the time for large-scale congregational singing, although some traditional hymns of his Prayer Book might have been used for this purpose.

\section{Jacobus Finno: Creating Lutheran Hymns}

The first Finnish Lutheran hymnal appeared around 1583. The writer of the hymns, the headmaster of the cathedral school of Turku, Jacobus Finno (c.1540-1588), had already lived all his life in a Lutheran kingdom. King John III appointed Finno to 'compile some useful books' in 1578. Apparently, those 'useful books' included Piae Cantiones (1582), the Catechism (c.1583), the Prayer Book (1583), and the Hymnal (c.1583). Except for the Piae Cantiones of Latin pious songs, ${ }^{53}$ these all belong to central Lutheran literature. The king's new liturgy in 1576 meant a shift back to some Catholic characteristics,

48 'Hyue Pappi luetta teste / wisust Canssas ilman este.// Saarnan Alghus / ia Lopus mös // nijn sine teutet sinun töös // Joca tas Latinan wnochtta / heijust se Canssans opetta' (Agricola I, p. 92).

49 Pajamo and Tuppurainen, Suomen musiikin, p. 46.

50 Berntson, Mässan och armborstet.

51 Lavery, 'The Reformation'.

$5^{2}$ Häkkinen, 'Mikael Agricolan, p. 19; see also Harjunpaa, 'A Historical Outline', pp. 157-8.

53 Lehtonen, 'Spoken, Written'. 
although not a complete retreat from the Reformation. Both the Prayer Book and Hymnal by Finno draw from the medieval Catholic tradition, reforming it according to Lutheran ideals. Finno's attitude to Lutheranism and Catholicism has been debated: it seems he was a moderate Lutheran, taking into account the changing political situations. ${ }^{54}$

The work of Finno redefined the relationship between books, genres, and performance practices in the field of Finnish liturgical and spiritual texts. The division between the books was explicit. His hymnal consisted of metrical songs, the prayer book of unmeasured prayers. In Finnish, this kind of division was a new one..$^{55}$ The Prayer Book by Agricola was a thick octavosized book of 877 pages with a heterogeneous content of unmeasured and measured texts, explanations, songs, and non-songs. The extensive liturgical material was clearly intended for the clergy, even though Agricola estimated it was light and small' enough to carry along when travelling, and even though his successor Paulus Juusten (1520-1575) claimed all the Finns used it daily. ${ }^{56}$ In contrast, Jacobus Finno's prayer book was, indeed, suitable for the laity, including lots of prayers for private use. The Church historian Jyrki Knuutila notes that this was close to Luther's view of the character of the prayer book. ${ }^{57}$

Both the prayer book and, most of all, the new Finnish hymnal marked a change in the Church's perspective on the laity. After the Catechetical Primer (Agricola 1543) and Catechism (Juusten 1574, Finno, c. 1583), these were the first books explicitly intended for congregational use..$^{8} \mathrm{In}$ his preface for the hymnal, Finno expressed his hope, analysed in the chapter by Tuomas M.S. Lehtonen, that these pious songs would even replace the impudent and shameless ones in secular use. ${ }^{59}$ Yet it is assumed that in the course of the sixteenth century, the amount of congregational singing in the service was still modest. ${ }^{60}$ Nevertheless, when a commoner of the seventeenth century had books, these were most likely the hymnal and some short version of the Catechism. ${ }^{61}$

Although Lutheran hymns were partly derived from pre-existing models, congregational collective singing was a new liturgical genre. It slowly

54 Finno, Jaakko Finnon; Lempiäinen, 'Finno, Jacobus'.

55 Juva, 'Jaakko Finno'; Kurvinen, Suomen virsirunouden, pp. 231, 256-312. The Hymnal includes only four unmeasured songs (the most popular biblical cantica at the beginning of the book), while Finno's Prayerbook contains only one metrical text, Veni sancte Spiritus from the Prayer Book of Agricola.

56 Heininen, Mikael Agricola, p. 189.

57 Juva, 'Jaakko Finno'; Knuutila, 'Hartauskirjallisuus', pp. 147-9.

$5^{8}$ Juva, 'Jaakko Finno'; Knuutila, 'Hartauskirjallisuus'.

59 Finno, Jaakko Finnon, p. 15; see also the chapter by Lehtonen in this volume.

60 Kurvinen, Vanha virsikirja, pp. 244-55; see also Herl, Worship Wars.

61 Laine, Vanhimman suomalaisen, p. 99. 
replaced some permanent unmeasured liturgical texts sung by the priest or choir in the Mass. Nils Holger Petersen points out that this transformed the structure of the Mass: in the medieval Ordinary of the Mass, only the melodies of the permanent texts changed according to the liturgical year. In contrast, in the Lutheran service, the changeable hymns replaced the parts of the permanent Ordinary, although some hymns were paraphrases of the previous parts of the Ordinary. Thus, what became stable was the basic structure of the Mass, rather than the permanent liturgical text. ${ }^{62}$

The Hymnal by Finno consists mostly of congregational hymns for the liturgy. The central themes relate to the Bible, the Catechism, and the ecclesiastic year. At the end there are also some songs for private devotion. Following the model of the Swedish Hymnal (1572), Finno included 101 hymns, grouped into a similar order. Nevertheless, the book is far from being a translation of the Swedish Hymnal. The translations are made from Latin, Swedish, and German. Finno created seven hymns from scratch, seventeen hymns he remodelled strongly, 65 he translated fairly directly, and seventeen were based on earlier translations by Agricola and others. Of Finno's hymns, sixteen are fairly direct translations and six are adaptations of hymns by Luther. ${ }^{63}$

Metrically, Finno's hymns do vary. In some rare cases, he follows quite strictly the numbers of syllables of his metrical model, for example in the Sapphic-like hymn 32. ${ }^{64}$ The most fixed features of this poem are the number of syllables $(11+11+11+5$; laupiudhes is read as three syllables here) and the use of rhyme, but in its nine stanzas, there is also a weak tendency towards a pattern of stress $(/ \backslash \backslash / \backslash \backslash / \backslash \backslash / \backslash / \backslash \backslash / D$, which does not exactly follow the classical Sapphic stanza.

\begin{tabular}{ll}
\hline O Herra Jumal armolinen Isä \\
Taiuan maan luoia ia mit ombi nijsä & $\begin{array}{l}\text { O Lord, God, merciful Father, } \\
\text { Creator of heaven and earth and of } \\
\text { what they contain: } \\
\text { Köyhiä lapsias laupiudhes cautta }\end{array}$ \\
$\begin{array}{l}\text { Your poor children through your } \\
\text { compassion, } \\
\text { Cuule ia autta. }{ }^{65}\end{array}$ & hear and help. \\
\hline
\end{tabular}

62 Petersen, 'Lutheran Tradition', pp. 43-4.

63 Kurvinen, Suomen virsirunouden, pp. 16, 86-90, 132, 256-312.

64 Kurvinen, Suomen virsirunouden, p. 272; Yxi Tarpelinen Nuotti-Kirja, pp. 38, 379.

65 Finno, Jaakko Finnon, p. 241. 
For the most part, Finno's models used iambic tetrameter. ${ }^{66}$ In these cases, he had several poetic strategies. The second example is a translation of the Latin hymn Veni Creator Spiritus, mentes tuorum visita ('Come, Creator Spirit') previously published in a non-rhymed version of iambic character by Agricola. ${ }^{67}$

\begin{tabular}{ll}
\hline TVle| pyhä| hengi| luoia & Come, Holy Spirit Creator, \\
Ja kijl|mäin sy|dhänden| suoia & the shelter of cold hearts, \\
Täytä| ne rin|nat ar|mollas & fill those chests with your mercy, \\
Qưin si|nä lo|it woi|mallas. ${ }^{68}$ & that you created by your power. \\
\hline
\end{tabular}

The first verse of trochaic character comes straight from Agricola, but other verses Finno has remodelled to make iambic patterns of stresses $(\backslash / \backslash / \backslash / \backslash)$ and rhymes $(\mathrm{AABB})$ more regular. Nevertheless, the sixth stanza of the same hymn illustrates how, indeed, without knowing the original model and melodic structures of Finno's songs, it would sometimes be difficult to say whether a pattern should be interpreted as iambic or trochaic:

\begin{tabular}{ll}
\hline Isä| meidhän| tuta| anna & Let us know our Father \\
Ja po|ian pääl| turuan| panna & and put our trust in the Son, \\
Sinu|sa mös| kijni| rippu & and hold on to You, \\
Joca| heistä| vluos| lijckut. ${ }^{69}$ & who proceed from them. \\
\hline
\end{tabular}

In this stanza, only the beginning of the second verse is made of two iambic feet, while all the others are clearly trochaic. The trochaic verses are calmly fitted into the iambic pattern in a way very typical of the early hymns. The number of syllables in a verse is stable, but the actual stress pattern is irregular.

On the other hand, in some other hymns it is the number of syllables in a line that varies. The third example of Finno's poems is a beginning of Luther's Ein feste Burg ist unser Gott ('A mighty fortress is our God'), a paraphrase of Psalm 46 (Deus noster refugium). The hymn by Luther is

66 Kurvinen, Suomen virsirunouden, pp. 76-7.

67 Kurvinen, Vanha virsikirja, pp. 17-18; Kurvinen, Suomen virsirunouden, p. 293; Old Hymn Tunes, No. 129.

68 Finno, Jaakko Finnon, p. 293.

69 Finno, Jaakko Finnon, p. 294. 
based on the number of syllables in the lines $\left(8+7+8+7+5^{+} 5^{+} 5^{+6+7}\right)$, but is not that strict with the actual stresses of the syllables. His long verses are of iambic character $(\backslash / \backslash / \backslash / \backslash(/))$, the short verses alternately trochaic and iambic. Finno applies this metrical pattern, and the melodies in later Finnish manuscripts and the choral books follow the melody by Luther. ${ }^{70}$

\begin{tabular}{ll}
\hline Meidhän lin|nam on| Jumal| taiuast $^{\circ}$ & Our fortress is God from heaven, \\
Meidhän| kilpem| ja o|tam & our shield and spear. \\
Hän autta| meitä häd|häst ia| waiuast $^{\circ}$ & He helps us from distress and trouble \\
Quin u|sein pääl|läm coo|tan & that often are gathered upon us. \\
Meidhän wi|holi|sem & Our foe \\
on hir|muli|nen & is terrifying: \\
Neuu|os ${ }^{\circ}$ mo|nis & In many crafts \\
ia pa|hois iuo|nis & and wicked guiles \\
Eij löy|tä hä|nen wer|tans.71 & on earth is not found his equal. \\
\hline
\end{tabular}

In his version, Finno uses from seven to nine syllables in long lines, where the original German poem uses an exact pattern of eight-seven-eight-seven. The shorter verses (originally 5-5-5-6) are from four to six syllables each. Additional syllables are, apparently, to be placed in non-stressed metrical and musical positions. In this way, it is possible to fit the translation to the melody. However, with some of the verses, it is difficult to say how the syllables should be placed into the rhythmic schemes of the metre and music, as the irregular stress pattern and verse length make several interpretations possible. Yet in this hymn, Finno ends all of the long verses with a two-syllable word or a second part of a compound $(\Lambda)$, which may be a way to add some regularity to an otherwise alternating realization of poetic patterns. In many other iambic tetrametric hymns, he tends to use three-syllable words at the ends of the lines.

In most of his hymns, Finno does not seem to care about the exact number or prominence of syllables. In one poetic position one or two syllables would do, and although there is a clear tendency towards iambic structures, occasional trochaic or mixed verses are also allowed. Nevertheless, in some cases, Finno preferred a stricter metre, either in regard to the number of

70 See Hallio, Suomalaisen virsikirjan, pp. 243-4; Kurvinen, Suomen virsirunouden, pp. 260-1; Yxi Tarpelinen Nuotti-Kirja, pp. 63, 380.

71 Finno, Jaakko Finnon, p. 196. 
syllables or to the pattern of stresses..$^{2}$ The first examples above show he was fully capable of doing this.

All in all, Jacobus Finno appreciated rhyme above all other poetic features. This is how he explicitly describes the hymns in his preface to the Hymnal: they are composed with rhymes, following the practice in other Christian regions..$^{73}$ Yet for him, the criterion of rhyme was looser than it tends to be nowadays. Words such as rippu/lijckut, otam/cootan and wiholisem/ hirmulinen would make a fine rhyme, although, when pronounced, they do not fulfil the modern demands for a proper rhyme. The main features of this poetic model are close to folk singing recorded in the following centuries, and in fact were also common in Swedish and German at the time. ${ }^{74}$

For Finno, as for Agricola, the old oral Kalevala metre was not an option. As Tuomas M.S. Lehtonen shows in his chapter, Finno strictly avoided alliteration, typical of oral idiom, in his work. Although his iambic verses may occasionally take trochaic forms, these do not get close to particular trochaic structures typical of the Kalevala metre, and he did not write trochaic hymns proper. ${ }^{75}$

\section{Hemmingius of Masku: Vernacularizing Poetics}

The next hymnal was a substantially extended edition of Finno's Hymnal, published by Hemmingius Henrici of Masku in 1605 . The extended hymnal came out in six editions through the seventeenth century, and when the subsequent extended edition was made in 1701, it still included nearly all the hymns by both Finno and Hemmingius with only some orthographical changes. ${ }^{76}$

Hemmingius continued the work of Finno. Besides editing and expanding the Hymnal, he translated into Finnish the collection of pious Latin songs, Piae Cantiones (Wanhain Suomen maan Piispain ja Kirkon Esimiesten laulud, 1616), and in his preface credited Finno with being the editor of the original anonymous Latin collection (1582). Hemmingius had studied at the cathedral school of Turku when Finno was the headmaster. He served as a vicar

72 See also Kurvinen, Suomen virsirunouden, p. 79 .

73 Finno, Jaakko Finnon, p. 15.

74 See Göransson, 'Musiken', p. 262; Laitinen, 'Barokki tunteen', p. 156; Kurvinen 1941, pp. 22-4.

75 Onni Kurvinen (Vanha virsikirja, p. 207) has analysed 76 of Finno's hymns as iambic, four as iambic with a strong trochaic character, fifteen as iambic with strong anapaestic character, two as Sapphic and four as unmeasured.

76 Knuutila, 'Virsikirjat, pp. 138-40; Kurvinen, Vanha virsikirja, p. 27; Lempiäinen 2000. 
of Masku parish (1586-1619). At the beginning of the seventeenth century, the reign of Charles IX marked a slow beginning of Lutheran Orthodoxy in Sweden. The Catholic aspirations had gone with the reign of John III and his son Sigismund. ${ }^{77}$ Unlike Finno, Hemmingius has three hymns about the papal Antichrist, and opposition to the Catholic Church is visible..$^{8}$

The second edition of the Finnish Hymnal includes 242 hymns, which was more than in any of the Swedish hymnals of the time. Hemmingius kept all the hymns of the previous edition and added 151 new ones, mostly translated or compiled from German, Swedish, Latin, and Danish originals or created by himself. Despite the additions, the basic order of the hymns is kept nearly the same. He made some orthographic changes to the preceding hymns, but otherwise very few editorial modifications. ${ }^{79}$ Yet for some of Finno's songs Hemmingius made his own parallel versions. At least six hymns are made by other translators. The central themes of the Hymnal relate to the Bible, the Catechism, and the ecclesiastic year, but Hemmingius added also some laments and wedding hymns. The book contains more hymns for private devotion than the previous edition: songs of praise, advice, prayer, and repentance. ${ }^{80}$

As a translator, Hemmingius was liberal. He chose the elements he most preferred from the versions in different languages, and added new elements quite freely. In a similar manner, he seems to have made his poetic choices according to the situation, sometimes preferring exact translation, sometimes his own version, using structural rhyme or abundant alliteration here and leaving it out there, and making occasional long verses that scholars from the nineteenth century on have tended to declare impossible to sing. ${ }^{81}$ Nevertheless, the hymnologist P.I. Kurvinen notes that the unstable character of poetic stresses surely did not prevent singing; the ethnomusicologist Heikki Laitinen points out the slow tempo of singing has made it easier to sing songs where the musical and poetic stresses did not always coincide,

77 Lempiäinen 200o; Kurvinen, Vanha virsikirja, pp. 14-25.

78 Väinölä 1995, p. 47.

79 Of the language of Hemmingius, see Häkkinen, 'Maskun Hemmingin'.

80 Kurvinen, Suomen virsirunouden, pp. 64, 166-70; Väinölä, Vanha virsikirja, p. 43; see also Laitinen, 'Barokki tunteen', p. 147.

81 On the critic of the early Finnish metrics see Krohn, Suomalaisen kirjallisuuden, pp. 44-50; Kurvinen, Suomen virsirunouden, pp. 78-80; Tarkiainen, Mikael Agricolan, pp. 8-9; Viinamäki, Hemminki Maskulainen; of the translating strategies of Hemmingius, see also Lehtonen, 'Spoken, Written'. 
and that, actually, for a folk singer it was not a problem to sing an occasional trochaic verse with an iambic tune. ${ }^{82}$

Hemmingius is often praised for his strong, expressive, and colourful language, but criticized for the structure of his verses. ${ }^{83}$ His versions of the first stanza of Veni Creator Spiritus and Psalm 46 (Deus noster refugium) show some of his poetic characteristics.

\begin{tabular}{ll}
\hline TUle| luoja| lohdhut|taja & Come, Creator, comforter, \\
Pyhä| Hengi| pyhit|täjä & Holy Spirit, sanctifier, \\
Ope|tus i|sä oi|kia & The righteous teaching Father, \\
Opill| oikjall| meit o|peta & Teach us with the right learning, \\
Ja hy|vydhel|läs pu|eta. ${ }^{84}$ & and dress us with your goodness. \\
\hline
\end{tabular}

Here, Hemmingius uses a different stanza structure (five verses) from Agricola and Finno (four verses). ${ }^{85}$ In the Hymnal, the version by Hemmingius is placed after the version by Finno, and marked 'The same, a little differently' ('Se sama vähä toisin'). The basic pattern of Hemmingius's hymn is iambic, but there are plenty of trochaic verses, as the two first verses of the song. The stress pattern often consolidates towards the end of the lines. The pattern of rhyme varies from stanza to stanza (AAABB/AABBB/ AAAAA/AABCC). What is striking here, compared to Agricola and Finno, is the amount of alliteration: very typically for Hemmingius, four out of the five verses of the first stanza in Veni Creator Spiritus include alliteration. Yet the amount of alliteration is not similar in all of his hymns. In the first stanza of Deus noster refugium by Hemmingius, there is alliteration in four verses out of seven:

82 Kurvinen, Suomen virsirunouden, p. 78; Laitinen, 'Vaan vahva'; Laitinen, 'Barokki tunteen', p. 156; Laitinen, Matkoja musiikkiin, pp. 183, 211.

83 See Laitinen, 'Barokki tunteen'; Lempiäinen and Haapalainen, Virsiavain, p. 58; Viinamäki, Hemminki Maskulainen.

84 Hemmingius, Yxi wähä suomenkielinen, p. N11a.

85 In the first Finnish choral book (1702), the same melody of five verses is given for both Finno's and Hemmingius's hymns. Finno's version is adapted to the melody by repeating the last but one verse, but in the manuscripts of the seventeenth century, there appears also a separate four-line melody for Finno's text (Kurvinen, Suomen virsirunouden, p. 319; Yxi Tarpelinen Nuotti-Kirja, p. 167; Old Hymn Tunes, nos. 129, 130). 
JUmal on meid|hän vä|kevä $\mid$ apum $^{\circ}$

Turva to|sin tus|kis suu|ris. ${ }^{\circ}$

Emme| siis pel|kä et|tä hucum ${ }^{\circ}$

Ehk mail|ma cu|kistuis juu|ri ${ }^{\circ}$

Vaick me|ri paohais, aal|lod cuo|huisid ${ }^{\circ}$

Vuored me|ren sy|vyten va|joisid ${ }^{\circ}$

Mäed mu|listuisid y|lis a|lais. ${ }^{086}$
God is our mighty aid,

Our most true shelter in great agonies.

Thus, we are not afraid of drowning, even if the world would fall,

the sea would roar, the waves foam, the mountains would sink into the deeps of the ocean,

the hills would turn up and down.

Instead of Luther's Ein Feste Burg, the content and form of this poem follows the paraphrase of Psalm 46 by Sebald Heyden and the Swedish translation with a similar metrical scheme. As a melodic clue, Hemmingius gives Finno's Nyt caiki Christityt ilotcat ('Now rejoice, all Christians', composed on the basis of Luther's Nunfreut euch lieben Christen gmeyn) of similar metric structure $\left(\backslash / \backslash / \backslash / \backslash(\|){ }^{87}\right.$ The pattern of rhyme in Hemmingius's poem is not as strict as in his models (ABABCCB), but varies along the poem. The poem contains notably less alliteration than the first example (25 verses of 42 , mostly weak alliteration). Compared to the iambic verse patterns in Luther's version with strict numbers of syllables and Heyden's poem with somewhat more varying patterns of eight and seven syllables in a verse, the poem by Finno is loose and the above example by Hemmingius even looser, containing from seven to ten syllables in a verse. ${ }^{88}$

A long verse like JUmal on meidhän väkevä apum may be divided into eight metrical positions (or musical structures) in several ways. ${ }^{89}$ Yet incomplete rhymes and irregular numbers of syllables were not uncommon in contemporary Swedish and German songs either. The biggest change in poetics is ascribed to Martin Opitz in the first decades of the seventeenth century. He insisted a good poem should follow either pure iambic or trochaic structure, should not include additional syllables or shortened words, and should be built with complete rhymes..$^{90}$ These are all features that were evidently not yet that important for the first Finnish hymn composers. Yet by the end of the seventeenth century they were felt problematic. In the first

86 Hemmingius, Yxi wähä suomenkielinen, p. C4a.

87 Kurvinen, Suomen virsirunouden, pp. 298-9.

88 See also Leaver, Luther's Liturgical, pp. 161-2.

89 The number of syllables in a verse was even larger for the singers in other dialects, who might complete the shortened words, ending up with twelve possible syllables in the first line: 'Jumala on meidän väkevä apumme.'

90 See Gasparov, A History, pp. 194-7; Gillespie, German Baroque. 
printed version (1702) of the melody of Finno's 'Now rejoice, all Christians', one additional note is inserted in several verses, in order to provide one suitable place for additional syllables.

Hemmingius also published a third version of Psalm 46. This poem, by provost of Turku Petrus Melartopaeus (d. 1610), is a translation of Luther's Ein feste Burg, and thus a parallel to Finno's version..$^{11}$

\begin{tabular}{ll}
\hline LInna| luja| on Ju|mala & God is a mighty fortress \\
Meidhän| myös vah|va vuo|ri & Our strong mountain also, \\
Sota|Herra| kyll ca|mala & A war-lord really terrible, \\
Tuki|turya| ja muu|ri. & supporting shelter and wall. \\
Vastan vai|noli|sii & Against the enemies \\
ja mur|ha mie|hii & and murder-men \\
Qvin surk|jan sur|maan & who to miserable death \\
ja juu|ri jul|maan & and very cruel \\
Meit ve|täväd van|hoi ja nuo|rii. ${ }^{92}$ & are drawing us, the old and the young. \\
\hline
\end{tabular}

Here, Melartopaeus uses meticulous numbers of syllables in a line. The first four long verses follow exactly the scheme of the German original (8-7-8-7), while the short lines with $5^{-6-5}-6$ positions are filled variably with $5^{-6}$ syllables. The last long verse of seven poetic positions is filled with nine syllables. The pattern of rhyme is similar to Luther's version (ABABCCDDB), although some rhymes are incomplete (vuori-muuri, vainolisii-miehii-nuorii).

From the point of view of poetic registers, the most interesting feature in these poems of the extended hymnal is the way the translators make use not only of abundant alliteration, characteristic of the old oral metre, but also of Kalevala-metric verse structures. First, some of the trochaic verses, although not all, comply with the rules of stress and length of syllables that is characteristic of Kalevala metre, such as TUle| luoja| lohdhut|taja - this is natural for trochaic poems. Secondly, some of the iambic verses containing an iambic inversion could, with equal ease, be read as typical so-called broken verses of Kalevala metre, where the short stressed syllables are placed at the unstressed positions of the trochaic verse ('Opill| oikjall| meit $\boldsymbol{o}$ |peta'; 'Vuored meren| syvy|ten $v a \mid$ joisid'; 'LInna| luja| on $J u \mid$ mala'). Thirdly, some of the iambic verses could be read as Kalevala-metric verses (where it is acceptable to have two to four syllables at the first foot), if the

91 Kurvinen, Suomen virsirunouden, pp. 318-19.

92 Hemmingius, Yxi wähä suomenkielinen, p. C3a. 
last shortened word is completed ('Siihen siis| linnan| turvad|cam(me)'; 'Ett olen| Herra| ja Ju|mal(a)'). Yet Hemmingius did not use features of oral folk poetry in similar amounts in all of his songs. In the second example above (JUmalon meidhän väkevä apum) the use of alliteration is more infrequent, and only very few verses connect with Kalevala-metric verse structures at all. In contrast, the five poems by Melartopaeus all strongly use various features of Kalevala-meter, although not representing the oral meter proper.

Indeed, the use of some Kalevala-metric features does not make these hymns Kalevala-metric. Yet it proves that Hemmingius and Melartopaeus did not make any attempts to avoid structures referring to the oral metre, if these structures were compatible enough with the basic iambic structures of their songs. In this tendency, they differed clearly from Finno and most poems published by Agricola. Nevertheless, they had one anonymous predecessor. Around the 1580 s, someone wrote Finnish adaptations of the medieval iambic hymns Surrexit Christus hodie and Ascendit Christus hodie in the Finnish parish in Stockholm. In these hymns, the basic structure of most of the verses appears Kalevala-metric, but by adding an occasional one-syllable word at the beginning of the verse and by contracting the last word the structure is reshaped into iambic tetrameter. Hemmingius used some verses of these songs in his own translations, but reworked the poems into more regular and iambic form.

Thus, Hemmingius and Melartopaeus combined features of different poetic song traditions in an innovative way. They used alliteration and various verse structures of old oral poetic idiom, but adapted these to new, stanzaic, and mostly iambic patterns. This may be interpreted as aesthetic vernacularization of the Lutheran hymn genre. They adopted features that were familiar and effective for the local congregations.

\section{Creating New Poetics and Practices}

The new Lutheran congregational singing was revolutionary in several ways. It gave the congregation a new voice and mode of presence in the service. It gave the rhymed, measured, stanzaic, vernacular poetry a new status and sphere of use in the Mass proper. It slowly transformed the most fixed textual parts of the Mass into varying hymns. The Divine Office (Liturgy of Hours) began to lose its importance, but some of its songs were translated into the vernacular and used in the Mass. The Reformation transformed a 
wide number of melodies, texts, and poetics for liturgical use, while also adapting many traditional medieval poems and melodies for Lutheran hymns..$^{94}$

During the Reformation, three major song genres were essential: unmeasured liturgical chant, Catholic measured songs, and Lutheran hymns. Medieval liturgical singing was mostly unmeasured, non-metrical chant, based on the Bible. Some metrical, stanzaic, even rhymed hymns were used, mainly in the Divine Office. There were also more complicated, polyphonic choral songs, some measured, some unmeasured. These all were kept in use. Yet, the central Lutheran invention was to slowly mould most of the liturgical singing into rhymed, stanzaic hymns that the congregation too would be able to sing. Lutheran hymns adapted texts and melodies from many directions: from medieval Catholic traditions, folk piety, earlier revivalist movements, and even from secular sources. The use of Lutheran hymns became widespread, and it has been regarded as one of the important factors in the popularity of the movement. Nevertheless, the process of making and adopting hymns and hymnals was not that quick even in Germany, despite the fact that Luther was not the first to promote vernacular religious singing. In Sweden both the clerical inclination towards non-measured chant and folk resistance delayed the process.

Luther and his followers used the most popular song language of the time, the rhymed song. The genre was already prevalent in German and Scandinavian vernacular culture and in Christian hymns, although the poetic forms in Swedish were not identical to those in German. Yet in Finland, the situation was different. There are no proofs of established rhymed folk song or hymn traditions in Finnish prior to the Reformation. The poetics and music of Finnish Lutheran hymns were new in very different ways from what they were in German and Swedish.

The new rhymed Finnish poetics was needed in order to connect to new Lutheran singing cultures. In Finnish, prior to the Reformation, there existed an alliterative, trochaic oral Kalevala metre with no stanzas or rhymes. Economical resources, individual poetic capabilities, changing political and religious atmospheres, international models, local traditions, vernacular song genres in various languages, and medieval Christian heritage affected

94 See Brown, Singing the Gospel; Burke, Popular Culture; Kurvinen, Vanha virsikirja; Leaver, Luther's Liturgical; Petersen, 'Lutheran Tradition'; Pettegree, Reformation; Schalin, Kulthistoriska studier.

95 See Brown, Singing the Gospel; Göransson, 'Kyrkans musik'; Herl, Worship Wars; Leaver, Luther's Liturgical. 
the composition of new songs. Consequently, the three earliest known poets of the Finnish Reformation made different poetic choices.

For Michael Agricola, singing in church was still based on traditional chant by priests and learned choirs, in the medieval manner. Agricola concentrated on the most important biblical and liturgical prose texts and their literal, explicit meanings, not on poetic forms - he even transformed some of the Latin metrical songs into vernacular prose. His song translations are traditional Catholic liturgical songs of various kinds, and the most metrical of these relate to the song traditions of the Divine Office. Agricola did not publish new Lutheran, measured hymns. Apparently, the most regular songs in his Prayer Book were translated by others and only published by him. In these songs the translator(s) mostly avoided alliteration that was typical to the old oral idiom. In trochaic poems, which is a form closer to the oral idiom, the avoidance was stricter than in the iambic ones, where the rhythmic structure in itself seems to have made the boundary between different poetic registers clear enough. The songs do not rely on rhyme, but in the most metric poems, the numbers of the syllables and the stress patterns tend to be quite regular.

Some thirty years after Agricola, the work of Jacobus Finno redefined the Finnish genres of Christian song and prayer. His books were intended for the laity as well as for the clergy. In particular, Finno created the Finnish Lutheran hymn. He emphasized rhyme as the distinctive feature of the genre, and made congregational singing both in the liturgy and in everyday practice a central goal of his Hymnal. For Finno, the use of regular rhyme, overall iambic style and fitting the words into particular melodies seems to have been more important than regular patterns of stress or exact numbers of syllables. He clearly avoided the alliteration and syllabic structures of Kalevala metre.

Around 1605, Hemmingius of Masku published a significantly extended edition of Finno's Hymnal. In his own translations and compositions, he used various poetic means in a flexible manner, varying the exact translation and free thematic improvization as well as the use of rhyme patterns and the amount of alliteration from poem to poem. Hemmingius and Petrus Melartopaeus were the first named Finnish poets to make abundant use of alliteration and structural features of Kalevala metre in hymns, although they did not compose any Kalevala metre poems proper. Like the vernacular poetics of the epoch in other languages, the stress patterns and numbers of syllables in the verse varied.

It seems the poems were, for Hemmingius as for Finno, primarily songs, meaning that the poetic structures had to fit into particular melodic 
structures, which typically meant that the maximum number of syllables in a foot (or two poetic positions) was four. In this chapter, the early hymns are looked upon as songs referring to and drawing upon various Catholic, secular, and Lutheran song registers, meant for mostly oral uses and taught to the congregations mainly orally. This alters some traditional attitudes relating to Finnish poetic metres and history of hymns.

Apparently, the unstable character of the poetic patterns was not a significant problem to the makers and users of the early hymns. For sure, when combined with irregular patterns of stress, placing several syllables in one poetic position leads to a range of interpretive possibilities. Technically, it is possible to place the syllables in a metric scheme or a melodic pattern in several different ways. This irritated modern critics, who claimed the earliest hymns impossible to sing. Certainly, it is impossible to analyse the poetic metre or to sing this kind of verse in an unambiguous way - but only if one is not familiar with the tradition and wants to proceed on the basis of the written text and a short musical notation only. In the practice of the sixteenth and seventeenth centuries, most of the learning of congregational songs took place orally. Consequently, the words and the rhythm of the melody were one inseparable unity. Learning the words meant also learning the proper ways to place them into the melodic structure.

To the classic questions relating to the early Finnish hymns - why were the songs so clumsy and why did they not make use of pure Kalevala metre-some additional observations can clearly be made. We cannot be sure that these poems that look clumsy to the modern reader really were that clumsy for their original audiences with rather different aesthetic ideals. In German, it was only Martin Opitz who, in 1624 , formulated the need to get rid of features such as additional syllables, irregular patterns of stress, shortened words, and incomplete rhymes.

Evidently, both Finno and Hemmingius wanted to bring a new Lutheran singing culture to the diocese of Turku and the Finnish language. The Lutheran congregational singing style was as much of sounds, melodies, rhythms, contexts of use, and styles of performance as it was of poetic metre. The structure of Kalevala metre would not have suited all of the hymn melodies. Indeed, Heikki Laitinen argues it is probable the early Finnish hymn-makers created their poems for particular melodies, not particularly following any abstract or strict metrical patterns. ${ }^{96}$ This would mean they attempted to create patterns that would sound enough like the Lutheran

96 Laitinen, 'Barokki tunteen', p. 153; Laitinen, Matkoja musiikkiin, p. 210. 
hymns in other languages. The oral Kalevala metre did not, indeed, sound similar to the iambic, rhymed songs in German and Swedish.

It was not possible to connect the new Lutheran song register with old poetics and musical styles. In this regard, the surprising thing is not the avoidance of the oral idiom by Agricola and Finno, but the way Hemmingius, Melartopaeus, and their anonymous predecessor actually did use some Kalevala-metric structures in the making of iambic poems. The choice of Hemmingius and Melartopaeus was to use both rhyme and alliteration, and combine Kalevala-metric and iambic tendencies, which resulted in intricate patterns still fitting into the overall rhymed, iambic structures and the new hymn melodies. It is possible that they felt Agricola and Finno had already made the division between vernacular hymns and oral folk poetry clear enough, enabling the genre boundaries to be stretched. Likewise, it is possible no-one before the 1580 s had thought it possible to connect Kalevala-metric features with rhyme and stanzaic structures, or apply those to an iambic scheme. Equally, Hemmingius and Melartopaeus may have searched for all the means at hand to make their songs as appealing as possible. In this quest, combining familiar structures of the Kalevala metre with fascinating new melodies, rhyme, and iambic and stanzaic structures was a successful strategy, as may be inferred on the basis of the popularity of these songs in folk use up to the nineteenth century. When dealing with the inclination of these clergymen to use features of vernacular poetics, it is also worth noting that it is supposed they spoke Finnish as their mother tongue or, in the case of Agricola, as a very strong second tongue. ${ }^{97}$ Thus, when they considered it proper, it was easier for them to use all the resources of language and oral tradition, than for most of their Baltic, German-speaking counterparts..$^{98}$

The slowness in creating the first Finnish hymnal may have been the result of the lack of resources and the laborious character of the task, as the German and Scandinavian metrical models really did not fit into Finnish as such. In addition, looking at Agricola's works and his attitude to many medieval traditions and the use of Latin, it seems evident that he did not view a new hymn culture as indispensable. The tendency was similar in Swedish, although the hymns were created earlier there.${ }^{99}$ Latin song traditions were held in high esteem in Finland, as shown by Hannikainen and Tuppurainen in this volume. The pious songs used in the Divine Office

97 Heininen, Mikael Agricola; Häkkinen, 'Maskun Hemmingin'; Lempiäinen, 'Finno, Jacobus'.

98 See Ross, 'Riimi sunnil', and the chapter by Grudule in this volume.

99 Göransson, 'Kyrkans musik'; Liedgren, Den svenska. 
and in cathedral schools, Piae cantiones, were published alongside the first hymnal and also translated into Finnish. The Church Order allowed the use of Latin songs in the Mass up to the early seventeenth century. Yet it is difficult to say how much this favouring of Latin and unmeasured songs was felt to be personally important by the clergy and how much it was intended to keep the laity content by minimizing quick changes in cult. In some Swedish parishes, several revolts arose to confront various changes brought about by the Reformation (see the chapter by Martin Berntson). In the conservative diocese of Turku, no revolts were seen.

When creating new Finnish poetics, the reformers had two practical constraints. They had their own ideals relating to various Latin, Scandinavian, German, and Finnish secular and sacred song genres. On the other hand, they must have been conscious, to some degree at least, of the constraints posed by their audience. They had to create songs the congregations would be able and eager to listen to, learn, and sing, but, in this quest, they made different poetic choices. Finno tended to use lucid, explicit, even somewhat laconic language, regular rhyme, and verse length. Hemmingius preferred vivid and strong language, alliteration with rhyme, and more varying verse lengths. It is impossible to say which would have made more catchy, contagious songs for they primary audiences:modern critics have preferred Finno for verse length and rhymes, but Hemmingius for alliteration and vivid language. Both wrote poems that were sung by the congregations and used as models for new hymns and folksongs alike up to the nineteenth century.

This chapter was written under the auspices of the Academy of Finland grant (Oral and Literary Culture in the Medieval and Early Modern Baltic Sea Region: Cultural Transfer, Linguistic Registers and Communicative Networks, project number 137906).

\section{Bibliography}

\section{Printed Sources}

Agricola, Mikael, Rucouskiria, Bibliasta, se on, molemista Testamentista Messuramatusta, ia muusta monesta, jotca toysella polella Luetellan, cokoonpoymettu Somen Turussa (1544). Reprinted in Mikael Agricolan teokset 1 (Porvoo: Werner Söderström, 1987) and published as a digital edition in Vanhan kirjasuomen korpus (Helsinki: Kotus). http://kaino.kotus.fi/ korpus/vks/meta/agricola/agricola_coll_rdf.xml.

Agricola, Mikael, Mikael Agricolan runokirja, ed. Kaisa Häkkinen(Turku: Turun yliopisto, 2012). 
Agricola, Mikael, Dauidin Psaltari (1551). Reprinted in Mikael Agricolan teokset 3 (Porvoo: Werner Söderström, 1987) and published as digital edition in Vanhan kirjasuomen korpus (Helsinki: Kotus) http://kaino.kotus.fi/korpus/vks/meta/agricola/agricola_coll_rdf.xml.

Das deutsche Kirchenlied: Kritische Gesamtausgabe der Melodien: Abt. 3: Die Melodien aus gedruckten Quellen bis 168o, ed. Joachim Stalmann, Hans-Otto Korth, with Renate Brocker, Rainer H. Jung, and Daniela Wissemann-Garbe (Kassel: Bärenreiter, 2010).

Codex Westh: Westhin koodeksin kirkkolaulut, ed. Erkki Tuppurainen (Helsinki: SibeliusAkatemia, 2012).

Finno, Jacobus, Jaakko Finnon Virsikirja, ed. Pentti Lempiäinen (Helsinki: Suomalaisen Kirjallisuuden Seura, 1988).

Hemmingius Henrici of Masku, Yxi wähä suomenkielinen Wirsikiria, suomencocouxis Jumalata kijttä suomenkielellä, / tehty M. Jacobilda Suomalaiselda, ja muild Suomen papeilda. Cunnjalisten herrain Turun pispan M. Erichin, ja capitularesten tied host ja suosiost, H. Hemmingin Maschun kirkoherran vaevall ja culutuxel. Mutta nyt wastaudest achkarast ylize catzotu (Stockholm, 1605). Published as a digital edition in Vanhan kirjasuomen korpus (Helsinki: Kotus): http://kaino.kotus.fi/korpus/vks/meta/virret/hemm1605_rdf.xml.

LW = Luther's Work. American edition (St. Louis: Fortress, 1955-1986).

Old Hymn Tunes Edition, ed. Erkki Tuppurainen (Helsinki: Sibelius-Akatemia) http://www2. siba.fi/virtuaalikatedraali/vanhatvirret/index_e.html.

WA = D. Martin Luthers Werke (Weimar: Hermann Böhlau, 1884-1929).

Yxi Tarpelinen Nuotti-Kirja. Vuoden 1702 painettu sävelmistö. Näköispainos ja kriittinen editio, ed. Erkki Tuppurainen (Helsinki: Suomalaisen Kirjallisuuden Seura, 2001).

\section{Literature}

Andrén, Åke (ed.), Sveriges kyrkohistoria. Reformationstid (Stockholm: Verbum, 1999).

Asif Agha, Language and Social Relations (Cambridge: Cambridge University Press, 2007).

Asplund, Anneli, 'Runolaulusta rekilauluun: Kansanlaulun murros' in Suomen musiikin historia 8:

Kansanmusiikki, eds. Anneli Asplund et al. (Helsinki: Werner Söderström, 2006), pp. 108-159.

Asplund, Anneli et al. (eds.), Suomen musiikin historia 8: Kansanmusiikki (Helsinki: Werner Söderström, 2006).

Anttila, Miikka E., Luther's Theology of Music: Spiritual Beauty and Pleasure Berlin: De Gruyter, 2013).

Berntson, Martin, Mässan och armborstet. Uppror och reformation i Sverige 1525-1544 (Skellefteå: Artos, 2010).

Bonn, Ann, 'Plainsong in the Lutheran Church', The Musical Times 114 (1973), 582-7.

Boynton, Susan, 'Prayer as Liturgical Performance in Eleventh- and Twelfth-century Monastic Psalters', Speculum 4/82 (2007), 896-931.

Boynton, Susan, 'Plainsong', in The Cambridge Companion to Medieval Music, ed. Mark Everist (Cambridge: Cambridge University Press, 2011), pp. 9-25.

Brown, Christopher Boyd, Singing the Gospel: Lutheran Hymns and the Success of the Reformation (Cambridge, Mass.: Harvard University Press, 2005).

Brown, Christopher Boyd, 'Devotional Life in Hymns, Liturgy, Music, and Prayer', in Lutheran Ecclesiastical Culture 1550-1675, ed. Robert Kolb (Leiden: Brill, 2008), pp. 205-58.

Burke, Peter, Popular Culture in Early Modern Europe. 3rd edition (Farnham: Ashgate, 2009). Duranti, Alessandro, Linguistic Anthropology (Cambridge: Cambridge University Press, 1997). Gasparov, Mikhail Leonovich, A History of European Versification (Oxford: Claredon Press, 1996). Gillespie, Gerald Ernest Paul, German Baroque Poetry (New York: Twayne Publishers, 1971). 
Göransson, Harald, 'Kyrkans musik', in Musiken i Sverige. Från forntid till stormaktstidens slut 1720, ed. Leif Jonsson, Ann-Marie Nilsson, and Greger Andersson (Stockholm: Fischer \& Co., 1994), pp. 231-300.

Göransson, Harald, 'Musiken under reformationstiden', in Sveriges kyrkohistoria 3: Reformationstid, ed. Åke Andrén (Stockholm: Verbum i samarbete med Svenska kyrkans forskningsråd, 1999), pp. 260-70.

Gummerus, Jaakko, 'Onko katolisella ajalla ollut suomenkielisiä virsiä?', Suomen kirkkohistoriallisen seuran vuosikirja 21 (1931), 333-53.

Häkkinen, Kaisa, 'Maskun Hemmingin kieli', in Hymnos. Soukat sanat, maistaa suu. Hemminki Maskulaisen virsikirja 40o vuotta (Helsinki: Hymnologian ja Liturgiikan seura, 2005), pp. 27-38.

Häkkinen, Kaisa, 'Mikael Agricolan elämä ja elämäntyö', in Agricolan aika, ed. Kaisa Häkkinen and Tanja Vaittinen (Helsinki: BTJ, 2007), pp. 13-23.

Häkkinen, Kaisa, 'The Rise of Literary Finnish', Cahiers d'études hongroises et finlandaises 18 (2012), 11-17.

Häkkinen, Kaisa, and Tanja Vaittinen (eds.), Agricolan aika (Helsinki: BTJ, 2007).

Hallio, Kustaa, Suomalaisen virsikirjan virret. Alkuperä ja kehitys (Helsinki: Suomalaisen Kirjallisuuden Seura, 1936).

Hannikainen, Jorma, Suomeksi suomalaisten tähden. Kansankielisen tekstin ja sävelmän suhde Michael Bartholdi Gunnceruksen suomenkielisessä Officia missce-introituskokoelmassa (1605) (Kuopio: Sibelius-Akatemia, 2006).

Harjunpaa, Toivo, 'A Historical Outline of Hymnody in Finland', Studia Theologica (Scandinavian Journal of Theology) 23 (1969), $156-72$.

Harvilahti, Lauri, The Holy Mountain: Studies on Upper Altay Oral Poetry (Helsinki: Academia Scientiarum Fennica, 2003).

Harvilahti, Lauri, 'Finland', in A Companion to Folklore, eds. Regina F. Bendix and Galit HasanRokem (Malden: Wiley-Blackwell, 2012), pp. 391-408.

Heininen, Simo, Mikael Agricola. Elämä ja teokset (Helsinki: Edita, 2007).

Helmer, Paul, 'Catholic Luther and Worship Music', in The Global Luther: A Theologian for Modern Times, ed. Christine Helmer (Minneapolis: Fortress Press, 2009), pp. 151-72.

Herl, Joseph, Worship Wars in Early Lutheranism: Choir, Congregation, and Three Centuries of Conflict (Oxford: Oxford University Press, 2004).

Hornby, Emma, Medieval Liturgical Chant and Patristic Exegesis: Words and Music in the SecondMode Tracts (Woodbridge: The Boydell Press, 2009).

Hymes, Dell, 'In vain I tried to tell you': Essays in Native American Ethnopoetics (Philadelphia: University of Pennsylvania Press, 1981).

Juva, Mikko, 'Jaakko Finno rukouskirjansa valossa', in Ramus virens (Forssa: Suomen Kirkkohistoriallinen Seura, 1952) pp. 72-109.

Kallio, Kati,Laulamisentapoja. Esitysareena, rekisterija paikallinen lajilänsi-inkeriläisessäkalevalamittaisessa runossa (Helsinki:Helsingin yliopisto, 2013). http://urn.fi/URN:ISBN:978-952-10-9566-5

Kallio, Kati, 'Kalevalamitta oppineiden käytössä uuden ajan alun Suomessa', in Elore 1 (2015).

Knuutila, Jyrki, 'Hartauskirjallisuus', in Vanhimman suomalaisen kirjallisuuden käsikirja, ed. Tuija Laine (Helsinki: Suomalaisen Kirjallisuuden Seura, 1997a), pp. 144-66.

Knuutila, Jyrki, 'Virsikirjat ja hengelliset laulukirjat', in Vanhimman suomalaisen kirjallisuuden käsikirja, ed. Tuija Laine (Helsinki: Suomalaisen Kirjallisuuden Seura, 1997b), pp. 134-43.

Korhonen, Mikko, 'The Early History of the Kalevala Metre' in Songs Beyond the Kalevala: Transformations of Oral Poetry, eds. Anna-Leena Siikala \& Sinikka Vakimo (Helsinki: Suomalaisen Kirjallisuuden Seura 1994), pp. 75-87. 
Krohn, Julius, and Kaarle Krohn, Suomalaisen kirjallisuuden vaiheet (Helsinki: Suomalaisen Kirjallisuuden Seura, 1897).

Kurvinen, Onni, Vanha virsikirja. Vuoden 1701 suomalaisen virsikirjan synty ja sisällys (Rauma: Länsi-Suomen kirjapaino, 1941).

Kurvinen, P.J.I. [Pietari Joonas Immanuel], Suomen virsirunouden alkuvaiheet vuoteen 1640, Suomalaisen Kirjallisuuden Seuran toimituksia 18o (Helsinki: Suomalaisen Kirjallisuuden Seura, 1929).

Kuusi, Matti, 'Questions of Kalevala Metre: What Exactly Did Kalevala Language Signify to its Users?', in Songs beyond the Kalevala: Transformations of Oral Poetry, ed. Anna-Leena Siikala and Sinikka Vakimo (Helsinki: Suomalaisen Kirjallisuuden Seura, 1994), pp. 41-55.

Laine, Tuija (ed.), Vanhimman suomalaisen kirjallisuuden käsikirja (Helsinki: Suomalaisen Kirjallisuuden Seura, 1997).

Laine, Tuija (ed.), Luther, reformaatioja kirja, Suomen Kirkkohistoriallisen Seuran toimituksia 220 (Helsinki:Suomen Kirkkohistoriallinen Seura and Suomen Teologinen Kirjallisuusseura, 2012).

Laitinen, Heikki, 'Vaan vahva virta vapaa. Aleksis Kivi Wanhan Wirsikirjan veisaajana', in Äidinkielen merkitykset, ed. Ilona Herlin, Jyrki Kalliokoski, Lari Kotilainen, and Tiina OnikkiRantajääskö (Helsinki: Suomalaisen Kirjallisuuden Seura, 2002), pp. 98-113.

Laitinen, Heikki, Matkoja musiikkiin 1800 -luvun Suomessa (Tampere: Tampere University Press, 2003).

Laitinen, Heikki, 'Barokki tunteen ja järjen dialogina: Hemminki Maskulaisen Uscovaisen sielun halu Christuxen jälken', in Hymnos. Soukat sanatmaistaa suu. Hemminki Maskulaisen virsikirja 400 vuotta, ed. Reijo Pajamo (Helsinki: Hymnologian ja Liturgiikan seura, 2005), pp. 143-63.

Laitinen, Heikki, 'Runolaulu' in Suomen musiikin historia 8: Kansanmusiikki, eds. Anneli Asplund et al. (Helsinki: Werner Söderström, 20o6),pp. 14-79.

Laurila, Vihtori, Suomen rahvaan runoniekat sääty-yhteiskunnan aikana (Helsinki: Suomalaisen Kirjallisuuden Seura, 1956).

Lavery, Jason, 'The Reformation in Finland - A Historiography of Continuities', in Religion and Identity in Russia and the Soviet Union. A Festschrift for Paul Bushkovitch, ed. Nikolaos A. Chrissidis, Cathy J. Potter, David Schimmelpenninck vân der Oye, and Jennifer B. Spock (Bloomington: Slavica, 2011), pp. 127-43.

Leaver, Robin A., Luther's Liturgical Music: Principles and Implications (Grand Rapids, MI: Wm. B. Eerdmans Publishing Co, 2007).

Lehtonen, Tuomas, 'Spoken, Written, and Performed in Latin and Vernacular Cultures from the Middle Ages to the Early Seventeenth Century: Ramus virens olivarum', in The Performance of Christian and Pagan Storyworlds: Non-Canonical Chapters of The History of Nordic Medieval Literature, ed. Lars Boje Mortensen and Tuomas M.S. Lehtonen, with Alexandra Bergholm (Turnhout: Brepols, 2013), pp. 107-39.

Leino, Pentti, Language and Metre: Metrics and the Metrical System of Finnish, Studia Fennica $3^{1}$ (Helsinki: Suomalaisen Kirjallisuuden Seura, 1986).

Leino, Pentti, 'The Kalevala Metre and its Development' in Songs beyond the Kalevala. Transformations of Oral Poetry, eds. Anna-Leena Siikala \& Sinikka Vakimo (Helsinki: Suomalaisen Kirjallisuuden Seura 1994), pp. 56-74.

Lempiäinen, Pentti, 'Finno, Jacobus (noin 1540-1588)', in Kansallisbiografia (Helsinki: Suomalaisen Kirjallisuuden Seura, 1997-; article created in 1998, updated in 2012) http://www. kansallisbiografia.fi/kb/artikkeli/2310/; URN:NBN:fi-fe20051410.

Lempiäinen, Pentti, 'Hemminki Henrikinpoika Maskulainen (noin 1550-1619)', in Kansallisbiografia (Helsinki: Suomalaisen Kirjallisuuden Seura, 1997-; article created in 2000) http:// www.kansallisbiografia.fi/kb/artikkeli/2327; URN:NBN:fi-fe20051410. 
Lempiäinen, Pentti, and T.I. Haapalainen, Virsiavain. Käsikirja virsikirjan käyttäjille (Helsinki: Kirjapaja, 1971).

Liedgren, Emil, Den svenska psalmboken: En historisk överblick (Stockholm: Sveriges kristliga studentrörelse, 1967).

Lippus, Urve, Linear Musical Thinking: A Theory of Musical Thinking and the Runic Song Tradition of Baltic-Finnish Peoples (Helsinki: University of Helsinki, 1995).

Maliniemi, Aarno, 'Kansankieli Suomen keskiajan kirkossa', in Novella plantatio, Suomen Kirkkohistoriallisen Seuran juhlakirja Suomen kirkon juhlavuotena 1955, ed. Aarno Malinniemi, Mikko Juva, and Kauko Pirinen (Helsinki: SKHS, 1955), pp. 105-12.

Niemi, Jarkko, The Nenets Songs: A Structural Analysis of Text and Melody (Tampere: University of Tampere, 1998).

Page, Christian, The Christian West and its Singers: The First Thousand Years (New Haven: Yale University Press, 2010).

Pahlmblad, Christer, Mässa på svenska. Den reformatoriska mässan i Sverige mot den senmedeltida bakgrunden (Lund: Arcus, 1998).

Pajamo, Reijo, and Erkki Tuppurainen (eds.), Suomen musiikin historia 7. Kirkkomusiikki (Helsinki: Werner Söderström, 2004).

Petersen, Nils Holger, 'Lutheran Tradition and the Medieval Latin Mass', in The Arts and Cultural Heritage of Martin Luther, ed. Eyolf Østrem, Jens Fleischer, and Nils Holger Petersen (Copenhagen: Museum Tusculanum Press, 2003), pp. 33-49.

Pettegree, Andrew, Reformation and the Culture of Persuasion (Cambridge: Cambridge University Press, 2005).

Pirinen, Kauko, Suomen kirkon historia 1. Keskiaikaja uskonpuhdistuksen aika (Porvoo: Werner Söderström, 1991).

Rapola, Martti, 'Vanhan runon kuvastelua parissa 500 -luvun virressä', Kalevalaseuran vuosikirja 14 (1934), pp. 149-69.

Ross, Kristina, 'Riimi sunnil sündinud elukas', Keel ja Kirjandus 7 (2013), pp. 522-528.

Sarajas, Annamari, Suomen kansanrunouden tuntemus 1500-17oo-lukujen kirjallisuudessa (Porvoo: Werner Söderström, 1956).

Schalin, Olav D., Kulthistoriska studier till belysande av reformationens genomförande i Finland, 2 vols., Svenska Litteratursällskapet i Finland 305, 313 (Helsinki: Svenska Litteratursällskapet i Finland, 1946-7).

Tarkiainen, Viljo, Piirteitä suomalaisesta kirjallisuudesta (Porvoo: Werner Söderström, 1922).

Tarkiainen, Viljo, Mikael Agricolan runot ja virret (Helsinki: Otava, 1929).

Tarkka, Lotte, Songs of the Border People: Genre, Reflexivity, and Performance in Karelian Oral Poetry (Helsinki: Academia Scientiarum Fennica, 2013).

Tedlock, Dennis, The Spoken Word and the Work of Interpretation (Philadelphia: University of Pennsylvania Press, 1983).

Tuppurainen, Erkki, 'Westhin koodeksi reformaatioajan kirkkomusiikin dokumenttina', in Tutkimuksia Westhin koodeksista, ed. Kaisa Häkkinen (Turku: Turun yliopiston suomen kielen ja suomalais-ugrilaisen kielentutkimuksen oppiaine, 2012).

Väinölä, Tauno, Vanha virsikirja. Vuoden 1701 suomalainen virsikirja (Helsinki: Kirjaneliö, 1995).

Viinamäki, Anna, Hemminki Maskulainen - virsirunoilija (Helsinki: Kotimaisten kielten tutkimuskeskus, 2005) http://kaino.kotus.fi/www/artikkelit/maskulainen/ [accessed 19.6.2014].

Voipio, Aarni, Virsiemme syntyja olemus: Evankelisen hymnologian pääpiirteet (Porvoo: Werner Söderström, 1940). 


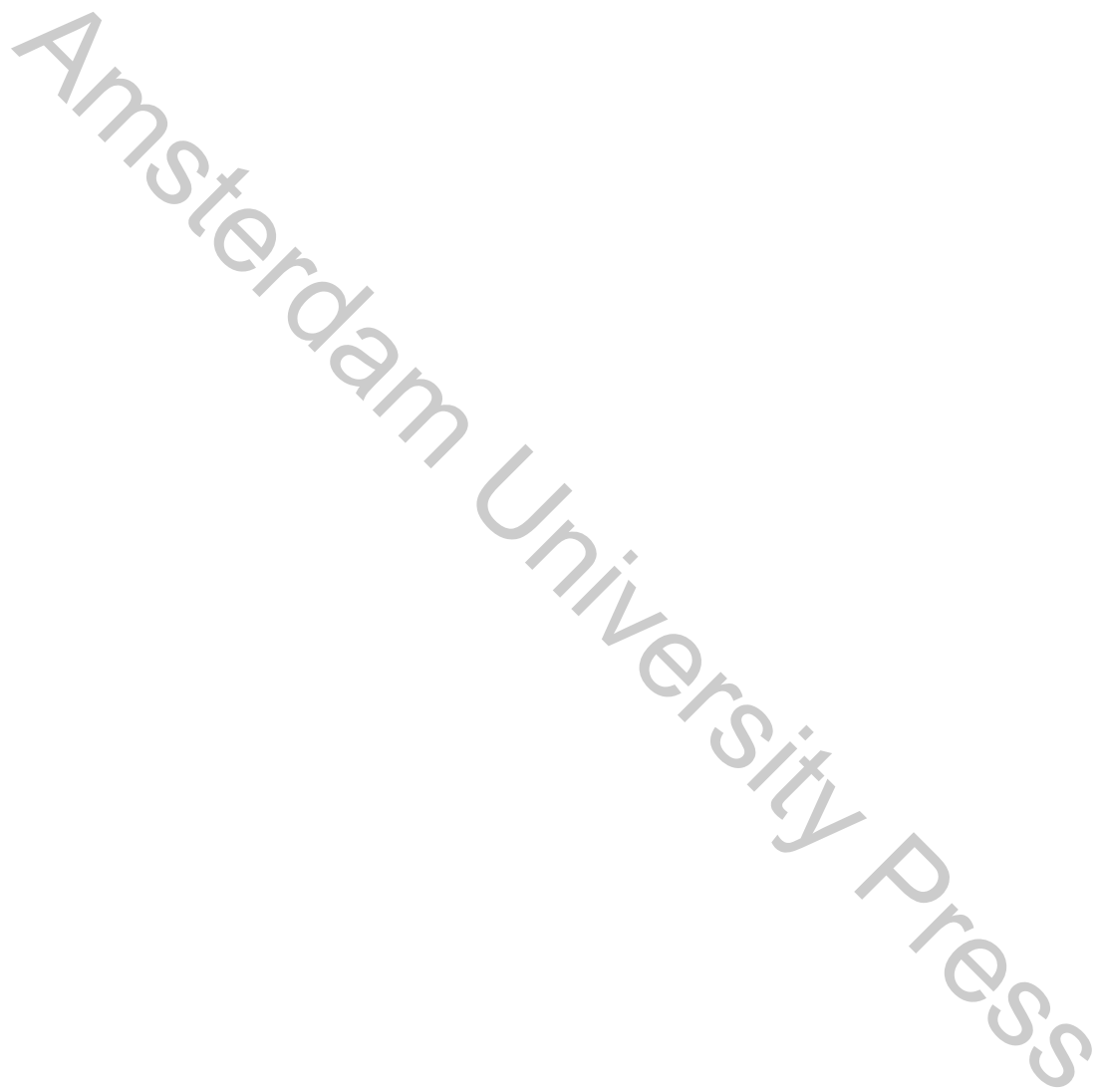

